\title{
Why are tropical rain forests so species rich? Classifying, reviewing and evaluating theories
}

\section{J.L. Hill ${ }^{1}$ and R.A. Hill ${ }^{2}$}

${ }^{1}$ School of Geography and Environmental Management, University of the West of England, Coldharbour Lane, Bristol BS16 1QY, UK

${ }^{2}$ Centre for Ecology and Hydrology, Monks Wood, Abbots Ripton, Huntingdon PE28

2LS, UK

\begin{abstract}
Two classifications are presented that organize the major processes and theories addressing the high species diversity of tropical rain forests. The first typology organizes environmental and biological processes within a spatio-temporal hierarchy, whilst the second classifies 12 theories according to over-arching driving forces: genetic differentiation, environmental change, niche/habitat diversification and biotic interaction. The theories are reviewed and evaluated by delineating the development and current state of academic knowledge pertaining to each. General issues that arise from examining species diversity within the tropical realm are discussed and this indicates where the academic debate stands today. Some thoughts concerning future research avenues are included.
\end{abstract}

Key words: biotic interaction, environmental change, genetic differentiation, niche/habitat diversification, scale, species diversity, tropical rain forest.

\section{Introduction}

This paper reviews and classifies the major theories that have emerged in more than a century of observation and research into tropical rain forest diversity. Two classification schemes are suggested. The first organizes theories around spatial and temporal scales and the alternative, simpler, framework classifies theories according to over-arching driving forces: genetic differentiation, environmental change, niche/habitat diversification and biotic interaction. This provides, in one source, a firm foundation of knowledge for those approaching the subject for the first time or seeking a concise overview. The theories are evaluated by delineating the development and current state of academic knowledge pertaining to each. This ensures that the breadth and complex- 
ities of tropical rain forest diversity are understood so that theories are not accepted uncritically or viewed in isolation. The discussion outlines the academic debate today as the subject remains actively researched and published. Scholarly research, polarized according to scale and discipline in the past, continues to focus within well defined boundaries. The future should concentrate upon co-ordinated research that collapses spatial and disciplinary boundaries using testable hypotheses.

Tropical rain forests have been described as nonseasonal, water-loving formations that are dominated by trees but are also rich in lianas and epiphytes. The undergrowth consists largely of tree seedlings, saplings and young woody climbers and the herbaceous ground flora is sparse (Schimper, 1903; Richards, 1996). Research into the diversity of this biome has largely concentrated on species richness/number rather than equitability, or the number of individuals that comprise each species. Tropical rain forests are renowned for their high species numbers. One hectare of primary forest usually contains over 100 tree species with a girth exceeding $10 \mathrm{~cm}$ and the number can reach almost 500 (Valencia et al., 1994). By comparison, temperate deciduous broadleaved forest attains only 25-30 tree species per hectare, at best (Richards, 1996).

Tropical rain forests have been revered as the most species-rich biome on Earth, harbouring over $50 \%$ of species on just $7 \%$ of the land area (Wilson, 1988). They do not comprise a unique diversity, however, in terms of species number or endemism. Some Mediterranean communities are comparable, such as the fynbos of Cape Floristic Province, South Africa; the mallee of southwest Australia; Californian chaparral and pockets of maquis/garrigue within the Mediterranean Basin. These areas have been identified as hotspots for biodiversity conservation along with many tropical forest sites (Myers et al., 2000). Coral reefs also possess high species diversity (Lugo et al., 2000) and there are areas of elevated oceanic diversity such as the Sargasso Sea. The processes that have created and continue to maintain the diversity of these ecosystems are fundamentally similar to those operating within tropical rain forests and they have also been differentiated according to scale (Aronson and Precht, 1995; Fraser and Currie, 1996; Cowling et al., 1996a,b; Schwilk et al., 1997; Van Woesik, 2000).

Partly because of a high plant diversity, tropical rain forests also harbour an enormous wealth of animals including various insects, amphibians, reptiles, mammals and birds. Ninety percent of primates (excluding humans) and $80 \%$ of all known insects are found in the tropical rain forests (World Wide Fund for Nature) (WWF), 1988). An emphasis on plant diversity will be maintained throughout this paper with secondary reference to animal diversity.

\section{Classifying species diversity theories}

Theories that attempt to explain the high species diversity of tropical rain forests must incorporate how diversity originated and how it is maintained. Thus, a range of historical biogeographical and contemporary ecological processes should be acknowledged when accounting for the variety of extant flora and fauna. The historical element incorporates evolution over millions of years: the life spans of vascular plant species are in the order of $1-5$ million years (Niklas et al., 1983). Extinction history is also important in countering species gain. Such processes tend to translate into biological patterns across large spatial scales, such as continents, and at higher taxonomic levels, such as 
families. They have dictated the origins of diversity and have provided a base of species upon which more contemporary processes work. Ecological processes operate over much shorter time scales and translate into small spatial patterns. For example, over 1000 species were re-established by regional immigration on the Krakatau island group, Indonesia, within a century of its destruction by volcanic explosion in 1883 (Whittaker et al., 1989). Such processes maintain or augment the diversity produced by historical biogeographical forces.

Figure 1 summarizes the spatial and temporal hierarchy of processes that have established and continue to regulate species diversity. The classification incorporates

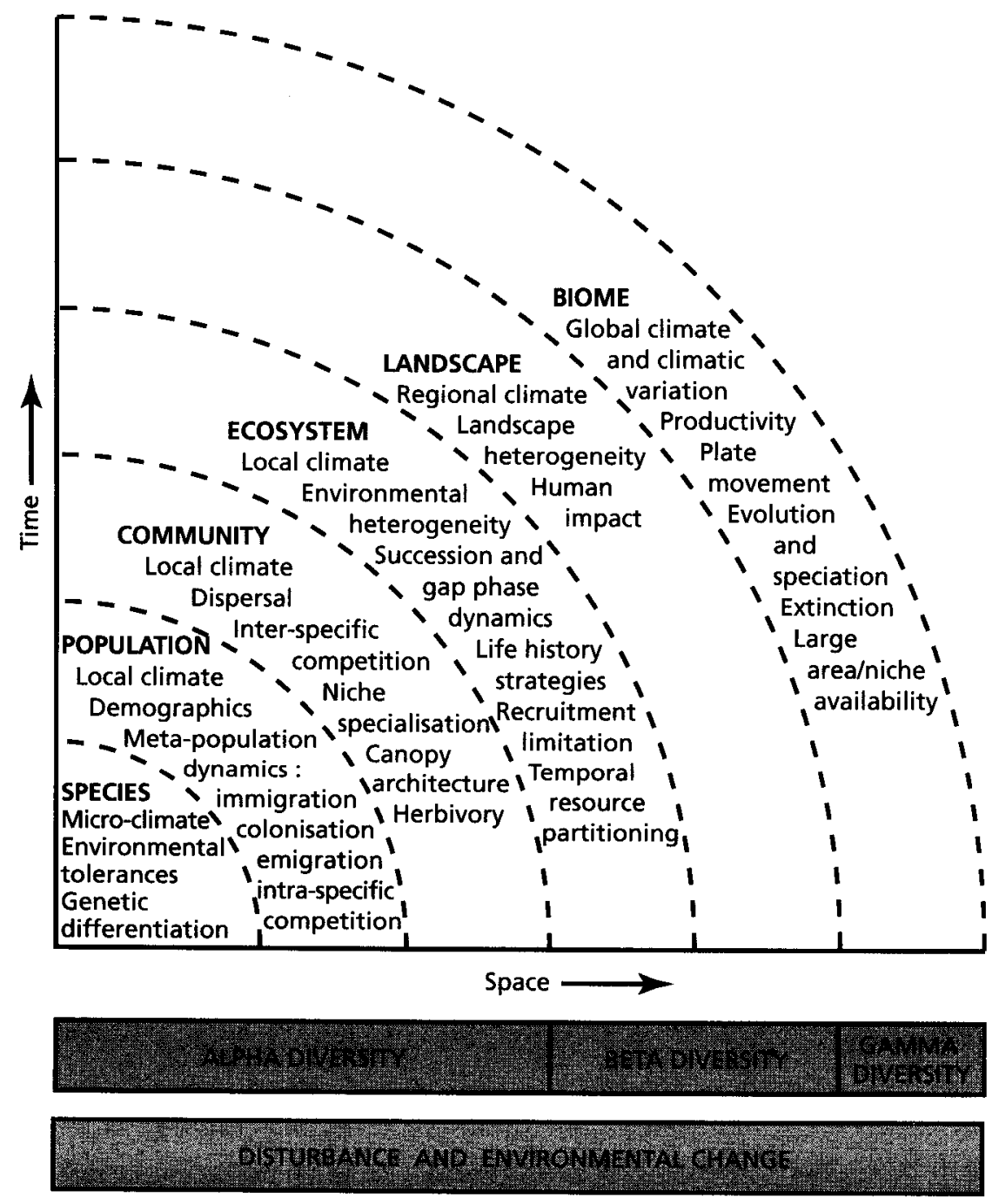

Figure 1 Spatial and temporal hierarchy of processes that establish and maintain species diversity (modified from Haila, 1990 and Tracy and Brussard, 1994). Reprinted with kind permission from the Ecological Society of America and Blackwell Science. 
both environmental and biological factors. It can be seen that the scale of investigation profoundly influences formative processes and patterns encountered on the ground (Meentemeyer and Box, 1987; Wiens, 1989; Holling, 1992; Cullinan and Thomas, 1992; Bian and Walsh, 1993). Landscape thresholds exist where pattern and process change distinctly. These thresholds are displayed as dashed lines in Figure 1 because, in reality, they cannot be defined with precision. The boundaries are necessarily arbitrary and subjective, with many processes transgressing into the neighbouring domains. Disturbance works across all spatial and temporal domains, from mountain-building events and plate movements to droughts and floods that create new habitats and reinitiate competition.

Diversity can be viewed, for convenience, across three spatial scales (Whittaker, 1972). Alpha diversity concerns species number within small homogeneous habitats. Processes that act to sustain diversity at this scale are niche diversification according to micro-spatial environmental variation, biotic interaction and gap dynamics following disturbance. Beta diversity describes between-habitat diversity or species turnover along environmental gradients. The key operative process at this level is habitat diversification according to topographic and geologic control. Gamma diversity describes regional/continental diversification resulting from formative allopatric and sympatric speciation under varied climates and physical environments.

Spatio-temporal scale can be viewed as a framework that is of fundamental concern to the understanding and organization of theories. The inherent complexities of the hierarchy, however, render it difficult to employ as a working typology. Consequently, this paper adopts the simpler framework of over-arching driving forces (Table 1) to review and evaluate theories of tropical rain forest species diversity, whilst continually clarifying their operation within the scale continuum as an interactive nested hierarchy of processes. The importance of and complexities inherent in prioritizing the processes that work across scale is examined in the discussion.

\section{Reviewing and evaluating theories}

\section{Genetic differentiation}

a Cumulative evolution: The theory of cumulative evolution is based on observations made by the early naturalists Charles Darwin (1845) and Alfred Russell Wallace (1878). This theory states that the rain forest environment, spared from the frequent disruption of winter and the occasional perturbation of glaciation, would have low extinction rates and hence accumulate species. Diversity is thus the product of both short- and longterm environmental stability that promotes long-term biome presence and allows time for speciation and co-evolution (hence the alternative name of the time-stability hypothesis).

Flowering plants do have a long history in the tropics, possibly evolving in the IndoMalayan region at the beginning of the Cretaceous, 135 million years ago (mya). Rapid evolution and adaptive radiation allowed out-competition of conifers and created forests similar to modern tropical rain forests at the beginning of the Tertiary (65 mya) (Cox and Moore, 1993). Evidence that flowering plants have been most abundant in the tropics for much of their geological past (in particular the Cretaceous period) has been 


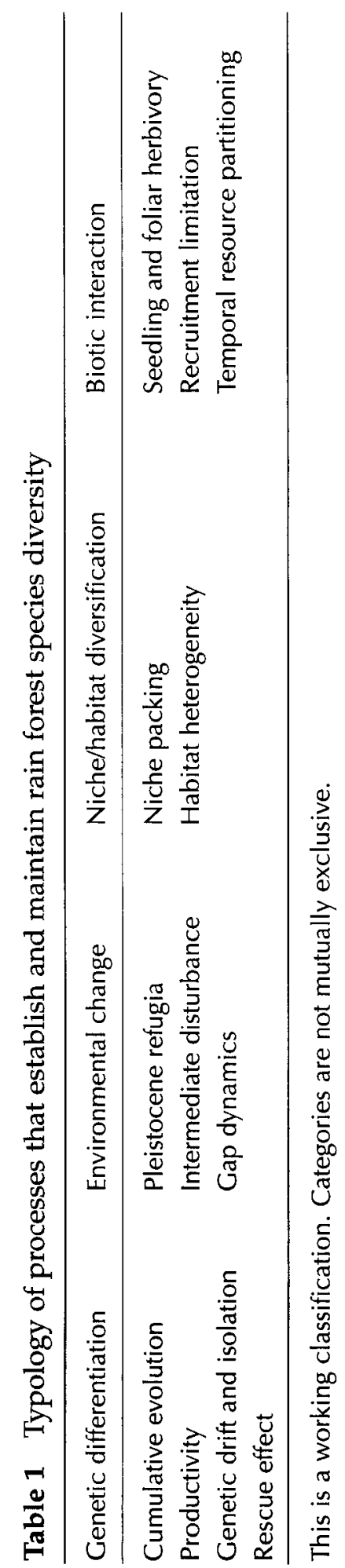


shown by Crane and Lidgard (1989), whose work supports both the origin and highest rates of angiosperm diversification in the tropics. Diversification is not only present at the species level but also at higher taxonomic levels such as the family and genus (Chown and Gaston, 2000). This lends credence to a long time-frame of evolutionary change. Primitive tree species that are commonly encountered in rain forests also support this theory, but it is partly dependent on environmental stability since the Tertiary and this belief is no longer held (see section III, 2).

Cumulative evolution is enhanced by interactive co-evolution. Co-evolution, the mutual adaptation of two or more species by complementary evolution (Allaby, 1994), can influence species abundance and distribution. For example, fig species are pollinated by symbiont species of wasps that can only breed in female flowers of their specific host (Anstett $e t$ al., 1997). This supports species continuity across generations. Figs are then involved in a two-phase dispersal process by vertebrates and ants (Kaufmann et al., 1991), which ensures their distribution over space. Hubbell and Foster (1986) have shown that co-existence of species occurs for hundreds of generations, which promotes the maintenance of diversity through time. The degree to which cumulative evolution is enhanced by co-evolution differs among species and it remains difficult to quantify.

$b$ Productivity: The rain forest climate is driven by a substantial energy input that maintains high monthly and average annual temperatures (approximately $18^{\circ} \mathrm{C}$ and $24-28^{\circ} \mathrm{C}$, respectively). Rainfall is heavy $(1700-10000 \mathrm{~mm}$ ) with either no dry season or a short dry period with fewer than four consecutive months experiencing less than 100 $\mathrm{mm}$ (Walsh, 1996a). This climatic favourability provides optimum conditions for plant growth (Connell and Orias, 1964). Rates of reproduction are elevated as little energy is expended on internal regulation. Large populations result, which incorporate healthy genetic diversity and reduce extinction. Productivity can be viewed not just as energy input, but also as the amount of energy captured and transformed into living matter per unit area and time. This provides a complex tree canopy to support biological heterogeneity (Morin, 2000). Thus, long-term productivity initially promotes the generation of viable species populations but it is also manifest within habitats through vertical stratification and enhanced niche processes.

Productivity theory alone cannot account for high diversity as species populations tend to be limited to levels well below those possible from energy considerations (Colinvaux, 1986). Negative correlations between plant species diversity and net primary production have also been found (Ashton, 1977) and the theory is difficult to test as trees have long life spans that do not respond rapidly to experimental manipulations of productivity (Morin, 2000).

$c$ Genetic drift and isolation: This theory postulates that species diversity is partly dependent on widespread self-pollination and population inbreeding owing to the scattered distributions of highly specialized plant species (Federov, 1966; Endler, 1982). It is increasingly recognized that speciation can take place without large-scale geographic isolation (sympatrically) (Figure 2(a)). In the presence of micro-environmental heterogeneity and with the absence of extensive gene flow, sympatric fragmentation of populations is possible, which can lead to random genetic drift, polymorphism and eventually to speciation. Speciation under these conditions makes a much smaller 
(a) Sympatric

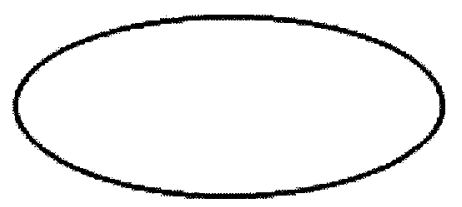

Original ancestral population

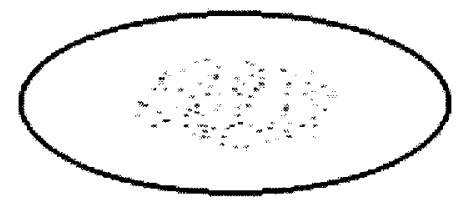

Polymorphism occurs

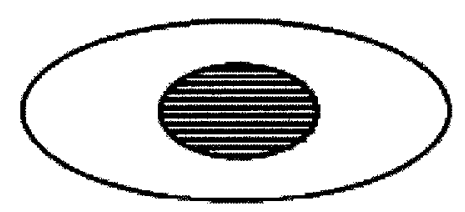

Divergent evolution within the population

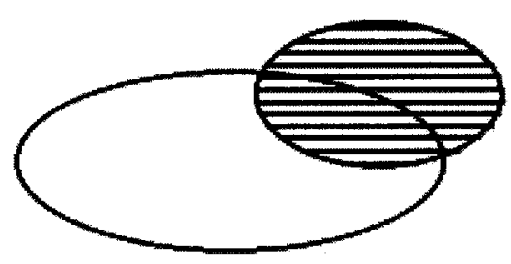

New genetically distinct species (b) Allopatric

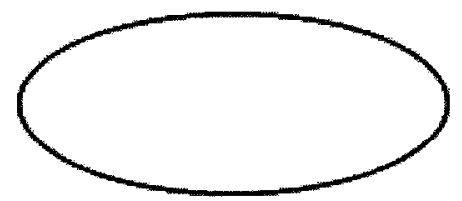

Original ancestral population Barrier formed

(e.g. mountain range, canyon, river)

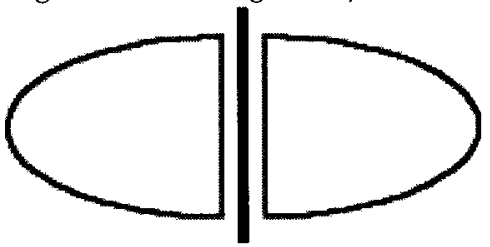

Geographic and hence genetic isolation

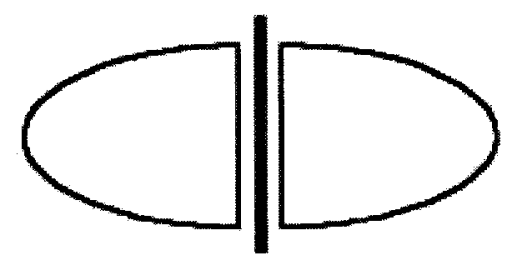

Genetic and morphological divergence of species under disparate environmental conditions

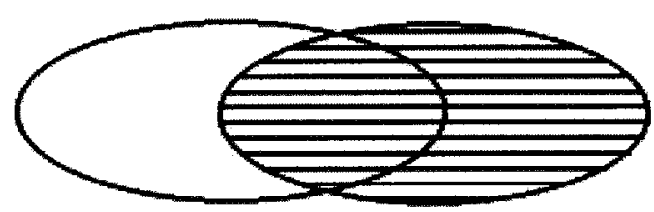

Amalgamation of the populations that remain genetically isolated as new species

Figure 2 Sympatric and allopatric speciation (from Krebs (1985), reprinted by permission of Pearson Education Inc) 
contribution to diversity than large-scale allopatric speciation (see Section III, 2, a). d Rescue effect: The work of Brown and Kodric-Brown (1977), concerning the principles of insular biogeography, has been applied to the tropical rain forest (Lewin, 1989). Species that are well adapted to a particular rain forest habitat provide colonists for habitats close by where such species are less well suited. The colonists are not outcompeted by superior species as their numbers are constantly replenished from the nearby source population. The influx of colonists maintains population numbers and ultimately the genetic health of the marginal community. Whilst the theory is embedded in landscape ecology and the contemporary concept of meta-population dynamics, the crux of sustaining genetic health ensures diversity is maintained over longer time-frames.

This theory provides an explanation for the maintenance of diversity at the periphery of species' ranges, but the authors did not find any empirical testing in the literature of its principles within the rain forest environment.

\section{Environmental change}

a Pleistocene refugia: It is now accepted that since the evolution of tropical rain forest, its boundaries have shifted constantly in response to climatic vagaries. Evidence for this is derived from geomorphological, geological and hydrological studies. Drier phases have been identified for Africa based on lake level evidence; satellite sensor images have detected fossil dunes under tropical forest; and deep sea cores near the mouth of the Amazon contain erosion products from an arid landscape (Damuth and Fairbridge, 1970; Colinvaux, 1979; Street-Perrott et al., 1985). Additionally, species distribution patterns in the humid tropics suggest that much of the forest has spread relatively recently from Pleistocene refuges. Haffer (1969) originally hypothesized that, during the Pleistocene, Amazonian tropical rain forest experienced alternating pluvial (wet) and interpluvial (dry) periods. The pluvial periods corresponded with temperate interglacials and, during these times, tropical forests expanded in area. During interpluvials (temperate glaciations), forests became fragmented into discrete blocks at high elevation, divided by lowland savanna. If separations mirrored glacial advances in the northern hemisphere, at least four, and possibly up to eight (Jones and Keen, 1993), isolations would have occurred which lasted 50000-100000 years (Terborgh, 1992). Evolution of distinct bird species is hypothesized to have occurred within these separate blocks owing to allopatric speciation (Figure 2(b)). This theory, supported by butterfly distributions (Colinvaux, 1979) and strengthened by similar patterns of mammal endemism in Africa (Grubb, 1982), is genetically feasible as smaller birds and mammals can generate new species in approximately 10000 years (Richards, 1996). When the forest blocks expanded and merged to form the present limits of Amazonia, the species within them would have already been distinct and formed centres of endemism, characterized by high species diversity. Repeated fragmentation in this way would have led to a 'species pump' providing a firm foundation for high diversity.

The theory has been challenged by studies of endemic lizard populations in Australia that support Pleistocene isolation but demonstrate little phenotypic evolution (Schneider and Moritz, 1999). Additional studies of skink populations have highlighted 
that natural selection operating across ecological gradients is more important than geographical isolation in generating phenotypic diversity and driving vertebrate speciation (Schneider et al., 1999).

Although the chronology of Pleistocene climate change is becoming increasingly well established, the size and location of forest refuges remains disputed. Pollen analysis has shown that a suspected upland refuge in Ecuador actually possessed a substantially altered montane flora during the Pleistocene and could not have served as a haven for tropical lowland species (Liu and Colinvaux, 1985). Indeed, many previously suspected refuges show considerable ecological change during the Pleistocene (Bradbury et al., 1981; Colinvaux, 1989; Bush et al., 1993). Perhaps riparian habitats along river banks provided key refuges, as such locations would have raised water availability locally. This hypothesis follows the work of Colyn et al. (1991) who studied primate distribution in the east central refuge of the Zaire Basin and concluded that the main areas of primate speciation were fluvial refuges. When glaciation ended, these centres were believed to give rise to a series of centrifugal dispersal routes that followed forest expansion, while the main rivers acted as barriers to dispersal. Recent research has added weight to this hypothesis, indicating that major river systems in the Neotropics have elevated species diversity through allopatric speciation (Meave and Kellman, 1994; Patton et al., 1994; Aide and Rivera, 1998).

Pollen analysis from the Amazon has shown recently that ice age climates were not sufficiently arid to fragment the lowland forest according to Haffer's predictions (Colinvaux et al., 1996; Colinvaux, 1997). According to this model, allopatric speciation occurred in highland forest experiencing cool temperatures and depressed levels of $\mathrm{CO}_{2}$. These highland areas were surrounded, and effectively isolated, by a sea of largely unchanged forest (Colinvaux, 1998). Thus, the refugia hypothesis has been turned on its head: temperate glaciations created an archipelago of genetically isolated 'islands' while the forest 'sea' remained intact.

The tropics cover a large area and within large landmasses the possibilities of species isolation and subsequent amalgamation are great. Hydrological conditions (Patton et al., 1994; Hoogihiemstra and van der Hammen, 1998), environmental heterogeneity (Endler, 1982; Gentry, 1989; Schneider et al., 1999) or pre-Quaternary climate change (Bush, 1994) can provide isolating mechanisms. Hence, more complex models that include a number of time scales and driving forces are coming into favour (Bush, 1994; Fjeldså and Lovett, 1997).

The credibility of Amazonian refuges remains disputed as they coincide neatly with collecting intensity (Nelson et al., 1990). Once an area of forest is investigated in detail, the number of species found there increases and it is considered a possible refuge. Such high diversity sites cover 60-80\% of the Amazon Basin (Prance, 1990; Rylands, 1990). Suspected refuges are currently areas of high precipitation and this condition alone might explain their high species diversity (Hall and Swaine, 1981). Furthermore, refuges can act as centres of extinction owing to super-saturation of species rather than as centres for species multiplication (Whitmore and Prance, 1987). Predictions of which outcome would prevail in any area are dependent upon time of isolation and area of refuge, together with the population parameters and niche requirements of the affected species.

Knowledge of tropical plant communities is consequently too incomplete to provide conclusive evidence for Pleistocene refuge theories and their importance may have 
been exaggerated (Connor, 1986; Gentry, 1992; Richards, 1996). Although evolution by allopatry is today viewed as a primary species pump, it should not be assumed that disjunct species distributions can be explained only by Pleistocene history. As previously stated, tropical rain forests have high diversity at the family and genus level, which indicates more ancient speciation. Equally, it should not be assumed that all speciation has occurred through large-scale geographic isolation over the longest time frames (Section III, 1, c).

$b$ Intermediate disturbance: Disturbance can be defined as any relatively discrete event in time that disrupts ecosystem, community or population structure and changes resources, substrate availability or the physical environment (Pickett and White, 1985). Natural disturbance varies in spatial extent, temporal frequency and magnitude. It includes old-age treefall and windthrow (Richards, 1996; VanderMeer and Bongers, 1996), channel erosion (Salo et al., 1986; Puhakka et al., 1992; Ferreira, 1997; Ferreira and Prance, 1998), fire (Kauffman, 1991; Kellman and Meave, 1997; Turcq et al., 1998; Cochrane and Schulze, 1999) epiphyte and strangler loading (Strong, 1977; Putz, 1984; van Shaik and Mirmanto, 1985), drought (Walsh, 1996b), cyclones and hurricanes (Whitmore, 1974; Imbert et al., 1998), lightning (Whitmore, 1984) and elephant activity (Martin, 1991).

Disturbance within ecological time scales is now viewed as an integral part of tropical forest ecosystem functioning. When intermediate in terms of intensity and frequency, it promotes high species diversity (Connell, 1978). With frequent disturbance, a community becomes dominated by those species that are capable of reaching maturity quickly; the so-called opportunistic, pioneer species (r strategists). With infrequent disturbance, community diversity is lowered as the most efficient competitors dominate; the long-lived, climax species ( $\mathrm{k}$ strategists). Intermediate disturbance promotes the highest diversity as time is available for invasion of species but not enough time elapses to allow competitive dominance by any one species (Figure 3). Disturbance interrupts the process of competitive elimination, thus maintaining local populations in a nonequilibrium state.

This theory is difficult to test as the intensity and rates of disturbance need monitoring accurately, together with the species response. A study in southeast Peru found patches of floodplain forest to have remarkably similar floristic composition despite suffering distinct disturbance histories. The intermediate disturbance hypothesis was thereby rejected (Terborgh et al., 1996). By contrast, a 30-year investigation of tree population dynamics in the Solomon Islands supported the hypothesis, indicating that periodic cyclones maintain differential composition between forest types (Burslem and Whitmore, 1999).

Whether such a fine balance between disturbance levels and interspecific competition can be attained such that extinction is not apparent at any one place, is somewhat dubious. However, in preventing climax communities from existing, species diversity is promoted as immediate pre-climax communities have higher species diversity than that of the climax (Odum, 1969). The theory has gained a strong foothold, possibly because the boundaries of what is meant by 'intermediate' remain diffuse and this leads to broad theoretical application.

c Gap dynamics: Disturbance within the ecological time frame maintains species 


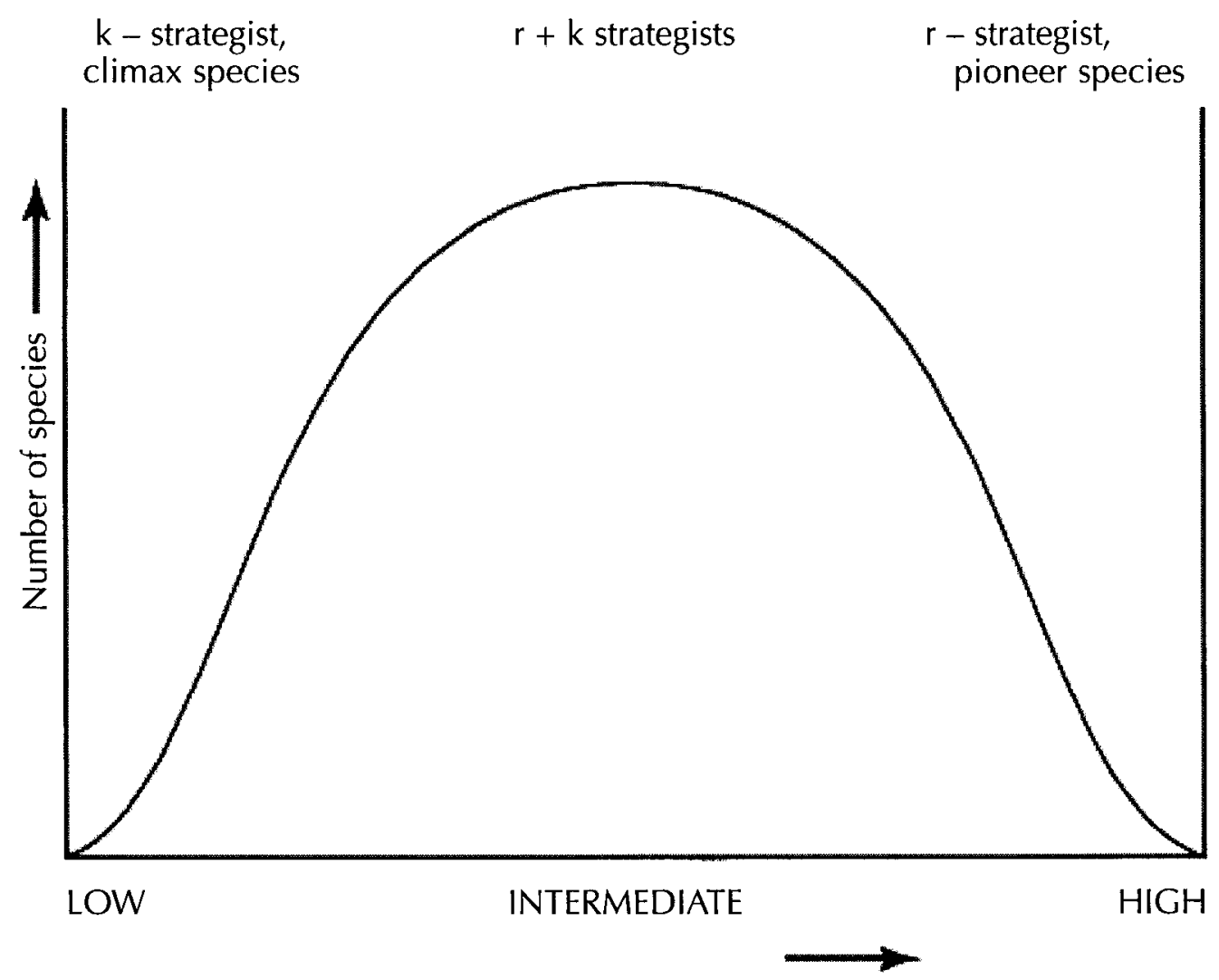

Figure 3 The intermediate disturbance model of Connell (1978). (Reprinted with permission from the American Association for the Advancement of Science.)

diversity over wide areas by creating a mosaic of different successional stages. Although a continuous process, growth after disturbance has been classified arbitrarily into gap, building and mature phases (Aubréville, 1938; Watt, 1947; Whitmore, 1978). Each phase has its own assemblage of species, but the exact nature of the successional process varies depending on the type of disturbance, size of gap and composition of original forest. The total gap area as a percentage of forest area ranges from $3 \%$ to $25 \%$ (Brokaw, 1985a). Gaps are filled with herbs, climbers and pioneer trees (such as Musanga cecropioides, the umbrella tree of West Africa), which originate from the seed bank, seed rain or sprout from tree stumps. Pioneers regenerate only under gaps in the forest canopy, where their dormancy is broken by an increase in the intensity of shortwave red light or by experiencing constantly high or alternating high and low temperatures (Whitmore, 1990; Martin, 1991).

Colonization and growth in gaps heralds the building phase and finally the mature phase with its closed canopy of climax species. Climax species are either light demanders or shade tolerators. Light demanders become established in shade and either benefit from or need light for further growth (Clark and Clark, 1987, 1992; 
Whitmore, 1989). Many timber trees such as Khaya are light demanders. Shade tolerators, such as Celtis mildbraedi flourish in the understorey of undisturbed forest but they grow slowly until a gap opens above them, permitting accelerated growth.

Pioneer and climax species are simply two ends of a spectrum of life histories (Alvarez-Buylla and Martinez-Ramos, 1992). Within each category there is a diversity of responses to constant light intensity (Davies, 1998) and variable acclimation to changing light intensities (Kursar and Coley, 1999; Brown et al., 1999). Additional regeneration guilds or plasticity of response may be a key to the high species diversity of tropical rain forest, but no unequivocal conclusions can be drawn until equivalent research has been undertaken within temperate forests.

There may be gap partitioning among regenerating species, each being adapted to a particular range of gap sizes (Pickett, 1983; Brokaw and Scheiner, 1989; Dalling et al., 1999) but recent studies from Danum Valley, Sabah, Borneo and Barro Colorado Island, Panama have disputed this (Brown and Whitmore, 1992; Hubbell et al., 1999). The latter study of 1200 gaps and 300000 trees over a 13-year period on Barro Colorado Island found that species composition in gaps was unpredictable (Hubbell et al., 1999). Also, internal heterogeneities and orientations mean each gap is case-specific in diversity according to partitioning of different light intensities (Raich and Christensen, 1989; MacDougall and Kellman, 1992; Kobe, 1999).

The response of tree seedlings to light variations in gaps makes an important (Brokaw, 1985b) but minor contribution to tropical forest plant diversity. A study of 250000 trees in Panama indicates that just 5\% are specialized to treefall gaps (Welden et al., 1991). The relevant continuum is actually extent of canopy closure and the light environment generally (Lieberman et al., 1988). Canopy regeneration as a response to light has been modelled in the absence of physical perturbation and treefall. Interactions between trees lead to a shift in dominance between individuals and hence to alterations in canopy composition (Moravie et al., 1997). Thus, niche differentiation in response to small changes in understorey light may be an important factor in the maintenance of intrahabitat diversity (Terborgh and Matthews, 1999; Svenning, 2000). This may reduce the problem of explaining the diversity of stable edaphic climax forests (Swaine and Hall, 1988).

\section{Niche/habitat diversification}

a Niche packing: Owing largely to its favourable climate and high annual productivity, a tropical rain forest is a resource-rich environment (e.g., photosynthetically active radiation, water, nutrients, leaves, fruits, flowers, seeds). Individuals of a given species can maintain viable populations only under a certain range of resource conditions (Figure 4(a)). For two similar species to reside in the same habitat they must partition resources. If the resource requirements of the two species overlap, the resources tend to become limited locally, interspecific competition occurs and one species will displace the other. The two species will subsequently continue to compete at their limits of tolerance (Gause, 1934; Hardin, 1960). An argument used for the tropics is that species are more highly evolved, interspecific competition is keener and hence species occupy smaller niches than in temperate areas (Figure 4(b)). The tropical forest environment is effectively saturated with species because of this intrahabitat niche packing 
(Hutchinson, 1959; Ashton, 1969; Richards, 1969). Additionally, the many resources effectively mean that a greater continuum is partitioned, which also boosts species numbers (Figure 4(c)).

As niche specialization is a simple, small-scale process that can be tested, it held popularity for many years. Comparative studies of species guilds in the tropics and

(a) Partitioning of resources by competing species

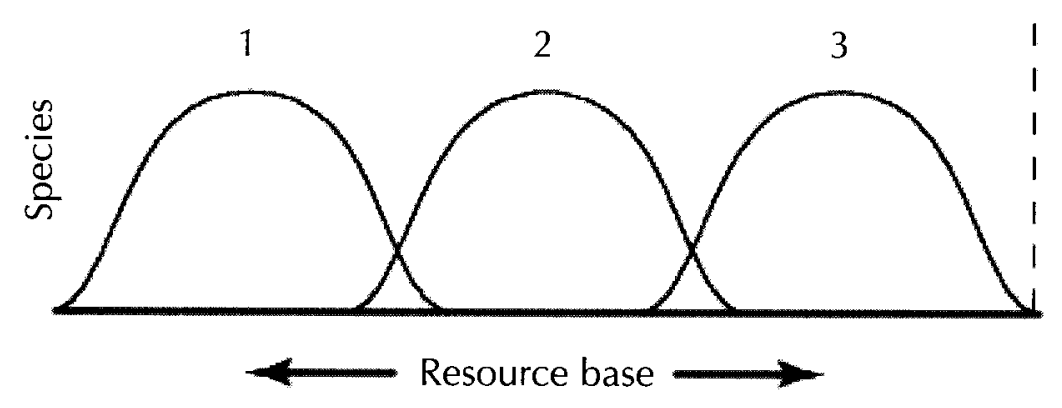

(b) Increasing specialization leading to niche packing

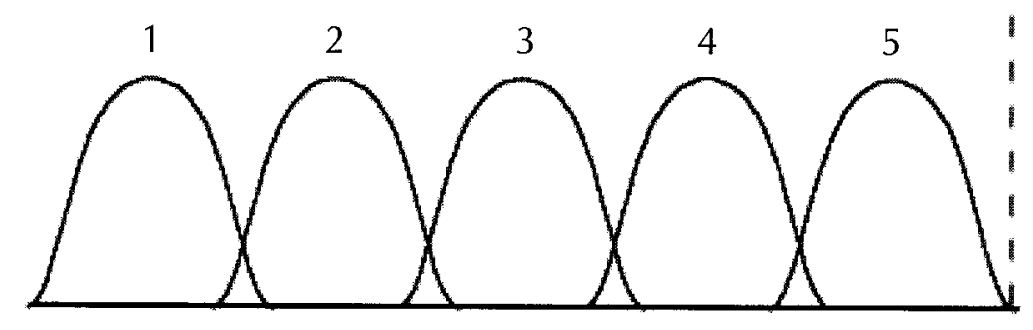

(c) Increasing the resource base

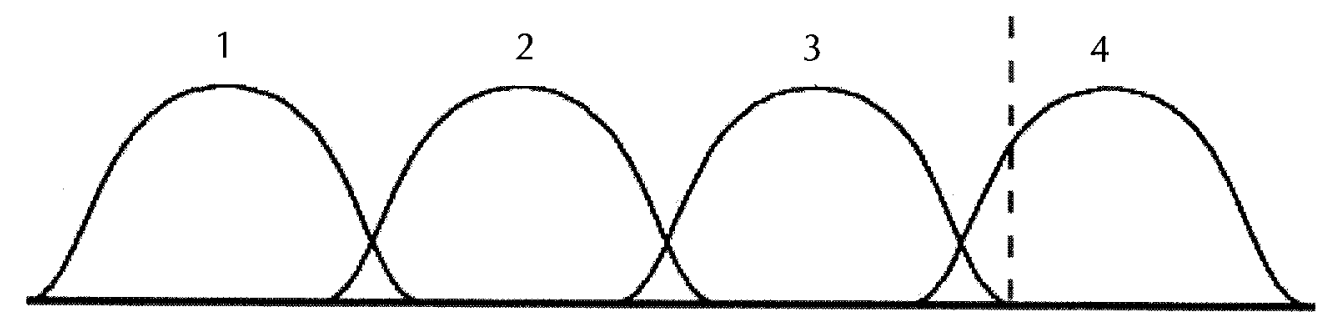

Figure 4 Raising species numbers through niche specialization or increasing the resource base 
temperate latitudes, however, have not always supported the proposition of tropical species partitioning niche space more finely, hence the theory is no longer unequivocally accepted (Terborgh, 1992). It is now appreciated that niche specialization has a relative role among other theories and is not a panacea for explaining species diversity (Hubbell and Foster, 1986). The theory accounts more effectively for species with closely related niches and dominant species with high densities.

$b$ Habitat heterogeneity: It is a common misconception that tropical rain forests are monotonous biomes, equivalent in terms of their structure and species diversity. In fact, any parcel of rain forest is unique at whatever scale is examined. Rain forests differ in terms of their environmental and evolutionary history, regional and local climates, relief, soils and hydrology (Bowman, 1996). Spatial heterogeneity results in many habitats and, as each species is competitively superior at exploiting a particular habitat sub-division, diversity can consequently be viewed as a function of the total range of habitats. This range is additionally enhanced by the large land area at the equator; the so-called latitude-area effect (Darlington, 1959; Rosenzweig, 1995).

The largest scale over which species diversity is normally examined is the region/continent (gamma diversity) (Richards, 1996). Tropical rain forest is found in four main regions; Central and South America, Central and West Africa, and IndoMalaya and Australia. Within a single continent, more than 20 forest types have been recognized in Amazonia, South America (Pires and Prance, 1985; Prance, 1977, 1983, 1996). These are usually classified hydrologically into terra firme and inundated forest formations. Terra firme forests include liane forest, heavily laden with climbers; palm forest; bamboo forest and whitesand forest, rich in insectivorous plants such as the pitcher. Inundated várzea forest is found along mildly acidic whitewater channels that are rich in sediments and emanate from Quaternary geology (e.g., the Rio Amazonas). Blackwater igapó forest skirts highly acidic, clear water that is discoloured from humic acids and tannins. Such rivers (e.g., the Rio Negro) have their source in older Tertiary formations. Igapó forest is dominated by palms and legumes but there are many variations depending upon local inundation regimes. Species diversity ranges between 21 and 137 species per hectare (Ferreira and Prance, 1998). Mangrove forest establishes between the tidemarks. Worldwide there are about 54 species of mangroves and there are another 60 species of flowering plant associated with them (Richards, 1996). Forest types are important in elevating diversity as many species are confined to one or only a few of the types (Whitmore, 1990).

Between-habitat, or beta diversity is frequently studied along hydrological gradients. In Venezuela, a horizontal distance of $1 \mathrm{~km}$ and a vertical rise of $20 \mathrm{~m}$ from a river course to well-drained uplands captures many different vegetation types (Terborgh, 1992) (Figure 5). Igapó forest occurs close to the stream where trees withstand seasonal immersion of trunks and roots. On sandy soils, high or low caatinga is found, depending on nutrient and water retention by underlying clays. Well-drained, higher oxygen clays support mixed terra firme forest. The species assemblages and level of species diversity varies between these different habitat types.

It has been suggested that high diversity correlates with soils of intermediate nutrient status, which slows growth rate and reduces the opportunity for competition (Iwasa $e t$ al., 1995). This is still debated, however. Species richness of seasonally dry Ghanaian forest has been inversely related to total exchangeable bases (Hall and Swaine, 1976), 


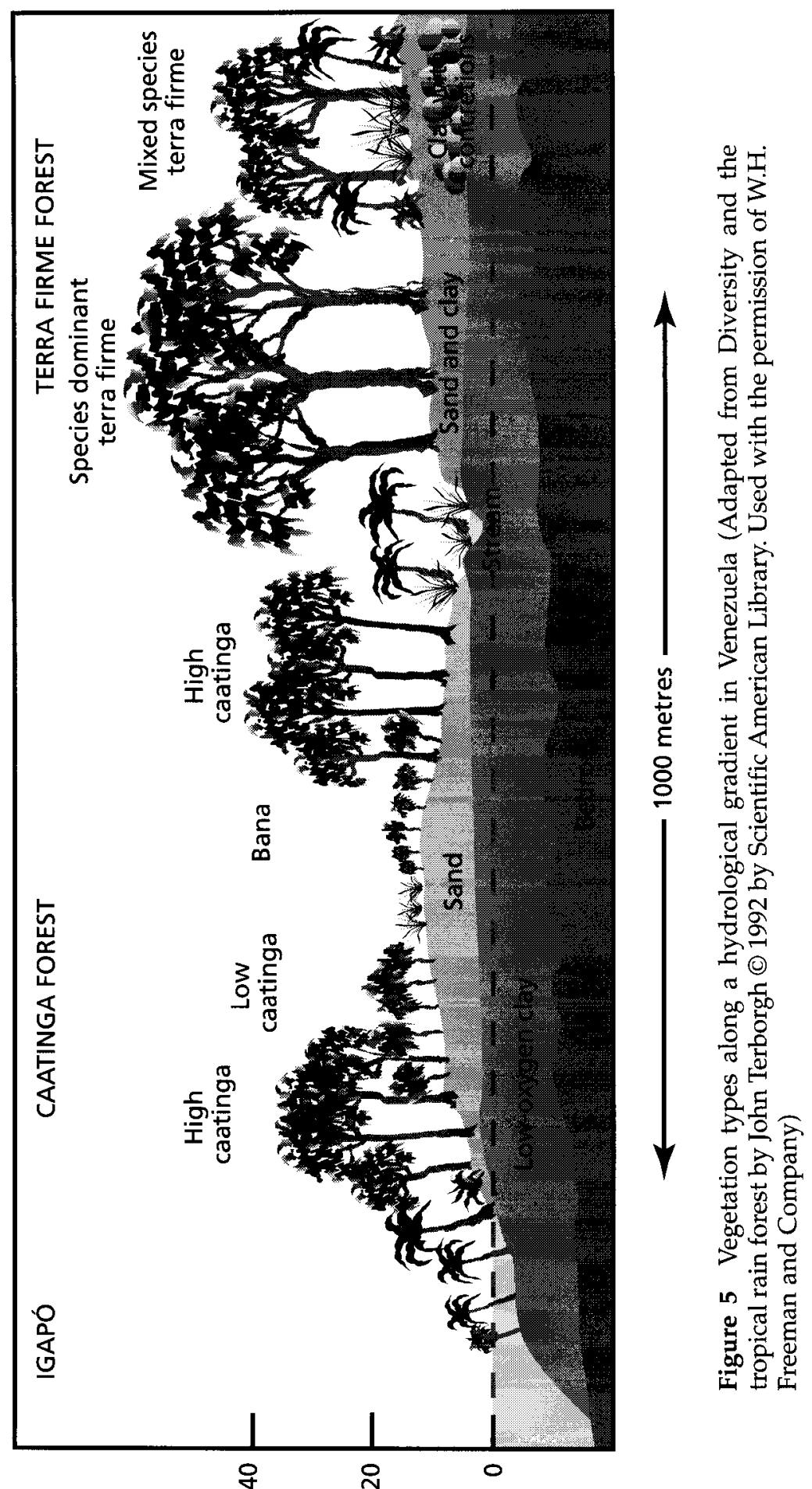

(รәлғәس) дчб!әч ләл! иеәш әлоqе ғчб!ән 
but in Sarawak no clear relationship was found between species richness and nutrient concentrations (Proctor et al., 1983).

Within habitat, or alpha diversity, is dictated largely by the complex rain forest architecture (Proctor, 1986). Vertical structure may be simplified into five strata; the A, B and $C$ tree canopies, shrub layer and herb layer. Whilst a simplification in view of gap dynamics and distinctive formations, forest stratification as an adaptive response to light is useful as an illustrative concept. Vertical partitioning of species occurs within these layers, such as the three species of colobus monkeys that occupy distinctive positions in West African rain forest canopies (Martin, 1991). The middle layers, with the densest foliage and moderated microclimate, are generally the most species-rich (Terborgh, 1992). Although it has been calculated that seven layers are required to explain the additional bird diversity in rain forest compared with temperate forest (Colinvaux, 1986), this number may be mediated by keen interspecific competition that leads to specialist feeding and thus niche packing.

Ecological diversity consequently varies enormously with topography, pedology and hydrology across a range of scales (Ojo and Ola-Adams, 1996; Newbery et al., 1996; Clark et al., 1999; Webb et al., 1999). In the Peruvian Amazon, a study of gamma and beta diversity has shown that satellite images of approximately $34000 \mathrm{~km}^{2}$ contain $21-54$ habitats, whilst a 30-km transect crosses an average of four different habitats (Tuomisto et al., 1995). Within the Tambopata-Candamo Reserved Zone of southeast Peru, an area of approximately $1500 \mathrm{~km}^{2}$, at least 14 different forest types have been defined according to location, soil type, species composition and vegetation structure (TReeS, 1994). Habitat heterogeneity may consequently allow tropical regions to accommodate more niches. Additionally, large-scale functional islands, such as inselbergs and sandstone table mountains in the lowlands of Amazonian rain forest, act to separate sub-populations and promote allopatric speciation (Prance, 1996). Alpha diversity is explained largely by the structural complexity of vegetation. Complex vegetation means many niches (MacArthur and MacArthur, 1961) and tropical trees are sufficiently specialized to allow 100 species to co-exist at equilibrium on a single hectare of forest (Connell, 1978).

\section{Biotic interaction}

a Seedling and foliar herbivory: This theory accounts for diversity maintenance over the scale of metres and it is usually examined at the species level. In the early 1970s, two authors independently hypothesized that seedling herbivory would act to increase the spacing between individuals of the same tree species (Janzen, 1970; Connell, 1971). Seed density is highest near the parent but so too is maximum seed predation by herbivores as this is the zone of maximum foraging efficiency. The probability of seed survival is highest further from the parent, although fewer seeds fall to the ground per unit area. At some distance from the parent tree, the decline in seed abundance is offset by increasing seed survival, so the population recruitment curve of three-month-old seedlings occurs some distance away (Figure 6). As a result, the space immediately surrounding the parental tree is invaded by other species. The distance of optimum recruitment from the parent tree is different from one species to another depending on seed dispersal distance and on the foraging habits of its main predators. Associated 


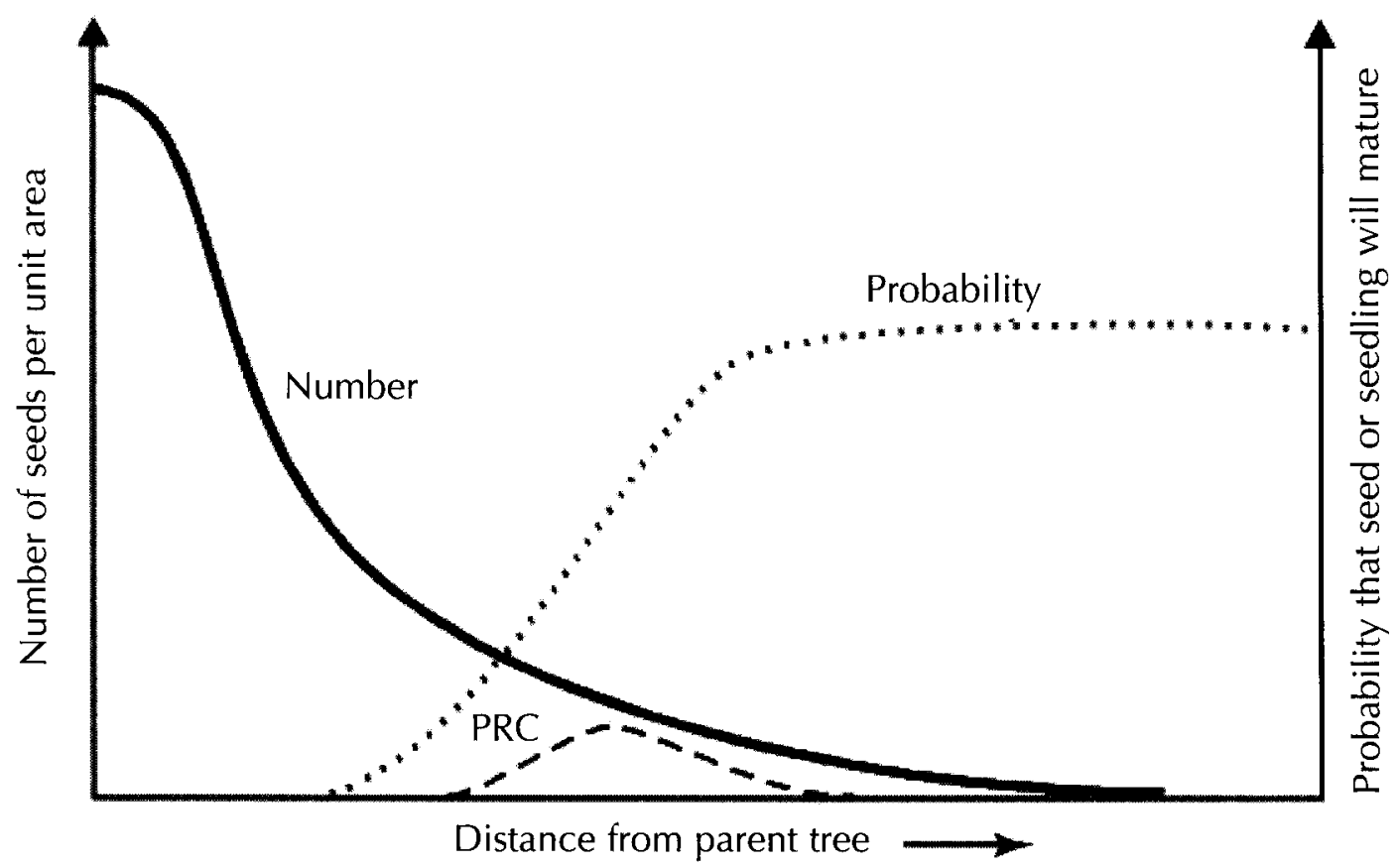

Figure 6 The Janzen-Connell hypothesis of seed and seedling herbivory. PRC, population recruitment curve (from Janzen (1970), reprinted by permission of the University of Chicago Press)

with such differential herbivory is the theory of compensatory mortality where herbivores attack and kill seedlings of common species more frequently than they attack those of less common species: in this way competitive elimination is prevented by the cropping process (Okuda et al., 1997; Penfold and Lamb, 1999). This may be of particular relevance in tropical regions where minimal seasonality allows year-round maintenance of herbivore populations (Colinvaux, 1986).

Herbivory theory requires predators, particularly seed-eating insects, to be hostspecific and there is some evidence for this, such as the high seedling mortality of Platypodium elegans near the parent owing to fungal pathogens (Augspurger, 1983). However, an examination of insect herbivores on 10000 seedlings of five tree species in Guyana found the majority to be generalist (Basset, 1999). A review of 24 tropical datasets supported the theory by finding evidence for mortality patterns as predicted by the model (Clark and Clark, 1984). This support continues today with studies from Panama, Malaysia and Guyana (Hammond et al., 1999; Wills and Condit, 1999). In Guyana the timing of Chlorocardium rodiei seedling attack varied along a distance gradient from conspecific adults, affording seeds further from the adults a window to germinate prior to attack. Time consequently regulated the influence of distance on local cohort recruitment (Hammond et al., 1999). Recent work on leaf chemistry of Nectandra ambigens, an upper canopy tree in Mexico, has refined the argument by discovering that seedlings chemically similar to the adults are absent under the tree canopy (Sanchez-Hidalgo et al., 1999). Such differential mortality might explain some of 
the cases where seedlings accumulate under the adult conspecifics contrary to the Janzen-Connell model.

Single dominant forests, which are found on all continents, conflict with the theory, possibly because of better protection from herbivory. In addition, a number of studies have found trees to be randomly spaced and not uniform as Janzen's model assumes (Ashton, 1964, Poore, 1968, Forget, 1992). Where herbivory is locally prolific, it provides a key mechanism maintaining an equilibrium state and preventing rare species from becoming too common. However, the process alone cannot explain the extreme diversity of tropical forests (Hubbell et al., 1990).

$b$ Recruitment limitation: It has long been known that dispersal limitation affects which species can arrive at a disturbed site and hence take part in successional development (Hubbell and Foster, 1986; Brokaw, 1987). More recently, this theory has been expanded and given the name recruitment limitation (Tilman, 1994). Recruitment limitation is the local absence of young superior competitors in sites favourable for their survival because of poor dispersal ability, low abundance or chance events. Whilst not preventing ultimate competitive exclusion, recruitment limitation allows inferior competitors to maintain local populations indefinitely. Recruitment limitation has been identified as a major factor maintaining local species richness in tropical rain forest gaps on Barro Colorado Island, Panama (Hubbell et al., 1999). The Panama study concludes that gaps promote diversity by increasing community-wide seedling establishment but the more obvious signature of species diversity is left by recruitment limitation.

c Temporal resource partitioning: Temporal resource partitioning refers to the differentiation between the timing of plant and animal activity (Mabberley, 1983). Tropical trees, whether animal or wind dispersed, tend to display seasonal variation in timing of fruitfall and seed germination (Lieberman, 1982; Mori and Brown, 1994). This causes a higher regeneration ability of the species for subsequent months and hence, among tree species, there is seasonal variation in germination advantage. Inter-specific competition is reduced and this allows many species to coexist (Runkle, 1989). Mathematical modelling of such seasonal regeneration patterns indicates that such phenological segregation can play an important role in maintaining regional tropical forest diversity (Iwasa et al., 1995). Continuity of fruit production, as different tree genera come into fruit, allows the proliferation of specialized nectarivorous or fruit-eating birds (Brown and Hopkins, 1996). Food supplies are plentiful but competition is minimized.

The temporal partitioning of niche space also takes place locally on a diurnal basis. Many small mammal species (e.g., pigs, muntjak) are nocturnal to avoid competition during daylight hours from larger ungulates (e.g. antelopes, elephants). The complex food webs of tropical rain forests make it almost impossible to test hypotheses concerning the competitive advantage gained from temporal resource partitioning. Temporal resource partitioning may alleviate interference competition but it does little to reduce resource competition. 


\section{Discussion}

Theories accounting for the high species diversity of tropical rain forests are not mutually exclusive but are integrated across temporal and spatial scales to explain species composition. Any explanation of species diversity is dependent upon scale, so unless scale is specified, comparisons are meaningless. Evolution is a first-order, largescale phenomenon: it is the foundation on which contemporary theories sit and it provides possibly the most powerful force that drives speciation: evolution by allopatry. Additionally, sympatric differentiation combined with environmental heterogeneity must be considered. Biotic species interaction is a lower-order, smaller-scale process.

Theories can be categorized using historical biogeographical or ecological labels but the somewhat hazy division of these categories and the transgression of processes across their boundaries renders such a polarized classification simplistic. This paper has highlighted the sometimes recurrent placing of theories along the continuum of scale. Thus, whilst it is true to say that evolution is a historical force with its origins millions of years ago, it follows the arrow of time through the present and on into the future. Likewise, processes that operate at the local level, such as niche packing, disturbance and herbivory, provide building blocks that are repeated and added to over regional and continental scales. Whether emergent properties arise through the integration of processes up the levels of organization remains a viable question but one that is almost impossible to test.

A key factor that elevates species diversity within tropical rain forests is that species numbers are high across all spatial scales. Locally high diversity is supported by regionally high diversity and vice versa. Different scales must therefore be examined to explain fully patterns of species diversity (He et al., 1996). This can be exemplified with reference to the Amazon Basin. Continental flora at the familial level reflects the isolation of South America from Central America and Africa during the Tertiary Period (Burnham and Graham, 1999) whilst disjunctions reflect refugial history, refined by cooler temperatures during the last glacial cycle. This distribution pattern is overlain upon vast regional environmental heterogeneity and disturbance. Speciation has been promoted across a range of scales owing to immense habitat variation within the basin. Erosion by lateral river meander occurs on century and decadal time-scales and seasonal climate in the north and southwest subject these areas to annual flooddrought cycles. Diversity within habitats has been promoted by local disturbance and consequent gap dynamics. Many isolating and disturbance events have been laid upon a varied environment, weaving threads of diversity that are difficult to disentangle.

The discussion above, concerning Amazonia, demonstrates that species diversity within the continental forest formations is mediated by a suite of processes, many of which are specific to that location and its enduring history. This is also true for IndoMalaya and Africa. Indo-Malaya's high species diversity can be explained partly by collision of the Gondwanan and Laurasian plates and the consequent mixing of taxa. This event did not, however, erase the dominance of the Dipterocarps, which are unique to this region (Whitmore, 1990). Allopatric speciation, influenced by the archipelago's insularity, has mediated species composition since the end of the last glacial period.

Africa is the least diverse of the continents harbouring rain forest. This is witnessed 
in species counts: $300 \mathrm{~km}^{2}$ of forest in Ghana holds only 191 mature tree species (Martin, 1991), whereas in Ecuador 313 mature tree species have been counted on one hectare (Korning and Balslev, 1994). Depressed diversity is due primarily to a long history of drought. Aridity following the end of the Oligocene Epoch (36 mya) led to widespread extinction in a previously rich forest (Axelrod and Raven, 1978). Set against this, has been the process of allopatric speciation owing to the division of the formerly continuous Guineo-Congolian forest. Bird studies demonstrate that the two forest blocks are quite similar but 14 species of bird are endemic to the Upper Guinea forests indicating divergent evolutionary histories (Dutson and Branscombe, 1990). Overall, inflated rates of extinction countered by divergence within Pleistocene refuges and continued differentiation under Holocene climatic variation have all contributed to a palimpsest of diversity in West Africa.

Tropical rain forests may exhibit primeval growth forms, but this does not mean that they have been without severe perturbations in the past or that they continue to suffer from disturbance. Disturbance over a range of spatial and temporal scales, from individual tree fall to the dissolution of continuous forest, is a factor elevating species diversity by increasing habitat availability and shifting competitive advantage. Equally, processes have continued over the lengthy time period that rain forests have existed on Earth, whether this be under regionally stable or unstable conditions. Cumulative evolution has elevated not only species number but diversity of higher taxa. The large land area at the tropics ensures environmental heterogeneity and thereby promotes sympatric speciation.

All rain forest theories must offer more than the possibilities that create and maintain the diversity of temperate forests. If herbivory, for example, promotes greater diversity in the tropics it must operate differentially across latitudinal belts. Tropical herbivores and plant pathogens must be either more specialized with respect to host plant species or their populations must be more sensitive to the density and dispersion of host populations. This calls for research across the globe, co-ordinated between tropical and temperate ecologists. Tropical rain forests do seem to provide a more varied mosaic of recruitment conditions than temperate forests. The intermediate disturbance model, for example, acknowledges a greater array of opportunities for invasion and establishment of tree species. The problem also exists of many key rain forest mechanisms acting in temperate areas, such as refugia (Flenley, 1993). Theories must offer testable hypotheses supported by empirical findings before temperate/tropical comparisons can be drawn.

As the refuge theory demonstrates, theories experience zeniths and nadirs and they are often reworked to regain acceptance in the academic arena. Theories should not be abandoned if they suffer place-specific or time-specific rejection, rather they should be re-examined and refined (Connor, 1986). Additionally, the application of old theories to new problems promotes scientific debate, such as the insular rescue effect of Brown and Kodric-Brown (1977) being applied to disjunct rain forest habitats. No matter how many deterministic hypotheses are tested and are not rejected there is always the role of chance in producing interpretable signals (Hubbell and Foster, 1986; He et al., 1996). A consistency of empirical findings is required such that significant differences in diversity represent patterns on the ground rather than sampling artefacts.

The dependence of species diversity on spatial scale is important for conservation. Forest reserves need to be situated in each phytogeographic zone to maximize species diversity. Once such gamma diversity is captured, ecotones may need targeting in order 
to preserve processes of sympatric natural selection that are important in maintaining species diversity (Smith et al., 1997). Alpha diversity must be studied in order to maximize niche diversification and biotic interaction. These are idealized principles that must be placed over political, social and economic backdrops. Conservation can prove difficult as when, based largely on endemism, richness and occurrence of rare and threatened species, priority areas for conservation cover $80 \%$ of the Amazon Basin (Rylands, 1990). Primary areas for reserves cannot be pinpointed easily and nonspecified areas are left with little protection.

Environmental, ecological and random factors shaping diversity must be understood so that the effects of drastic habitat destruction on biodiversity can be predicted (Dobson, 1996). Tropical forests are suffering from increasing anthropogenic reduction and fragmentation (Sayer and Whitmore, 1991; Whitmore and Sayer, 1992; Skole and Tucker, 1993; Rignot et al., 1997; Shimabukuro et al., 1998). Fragmentation tends to lower species number and alter community composition such that the rare, shade-tolerating, climax species decline (Hill et al., 1994; Hill, 1995; Turner, 1996; Laurance and Bierregaard, 1997; Laurance et al., 1998; Tabarelli et al., 1999; Hill and Curran, 2001). Increasingly, tropical rain forests are becoming degraded by less noticeable threats such as selective harvesting of plants and animals, biological invasions, pollution and climate change (Phillips, 1997).

The development of theorizing in the past partly explains the current state of knowledge pertaining to tropical rain forest species diversity. At the turn of the century the study of diversity lay within the realm of the historical biogeographers who speculated upon patterns of diversity at global and continental scales (e.g., A.R. Wallace). Mid-way through the century community ecologists began to debate the ecological processes that structure the community (e.g., G.E. Hutchinson and R.M. May). Researchers examined how local interactions among species, such as competitive exclusion, could regulate community diversity (Ricklefs, 1987). An examination of the refereed journal articles cited in this paper demonstrates that the polarization of research into historical/vicariant biogeography and population/community ecology has largely continued throughout the 1980s and 1990s. Journals such as Trends in Ecology and Evolution and Journal of Biogeography contain articles that concentrate on gamma diversity and historical processes, whereas articles in Journal of Ecology, Ecology and Biotropica concentrate on alpha and beta diversity, mediated by more contemporary population and community dynamics. Only articles in the journal Science demonstrate a history of cross-scalar publishing and it has been joined more recently by Biodiversity and Conservation. It is only natural to concentrate funding and research at a focused spatio-temporal level. After all, the hypothetico-deductive method of scientific enquiry requires examination of the particular. Each bite-sized piece of information adds to the overall picture, but herein lie further complexities. Partitioning according to discipline and spatio-temporal scale makes it difficult to benchmark formative and sustaining processes. It becomes impossible to separate the importance of processes acting at different spatial and temporal scales and hence to quantify their importance. This is what the deductive method of science has achieved so well for other biogeographical problems such as the theory of island biogeography (MacArthur and Wilson, 1967). With tropical rain forest diversity, we are unable make authoritative statements about the most important factor controlling diversity in any one region and we are far from prioritizing a suite of nested factors whose presence is felt along a scale continuum. At 
present we have all the pieces for the jigsaw but the relative sizes of the elements that comprise the picture are still unknown. Collaboration between disciplines would allow the full picture to become visible. Disciplines from palaeontology and evolution to autecology and genetics must be embraced. Increasingly, knowledge of complicated mathematical modelling and statistics is required (Cook, 1998). A range of considerations from the synergies of ecosystem interaction to discrimination of genetic information will provide a thorough understanding of the mechanisms initiating and maintaining biological diversity. This information must be contextualized within the landscape and integrated with meta-population dynamics to provide a fully comprehensive examination of tropical rain forest diversity.

Explaining tropical rain forest species diversity remains a complex issue, as evident in the carefully chosen words of Manrubia and Sole (1996) who state that simple rules operate within a complex and chaotic system. Permanent plots are now giving direct insights into processes rather than inferences being made from observation of distribution patterns. Direct monitoring of processes may prove helpful in unravelling the relative importance of contemporary theories, particularly those that require dynamic meta-population study, such as the rescue effect and recruitment limitation (Phillips et al., 1997, but see Sheila, 1996). After over a century of research and much advancement of knowledge, Whitmore's (1974) adage remains the best and purposefully guarded conclusion: tropical rain forest species diversity is not open to any single or simple explanation, but is due to a complex interplay of factors that must be resolved individually for any particular forest. The way forward is to build upon the many theories and principles to produce an integrated science.

\section{Acknowledgements}

The authors wish to thank Paul Revell at The University of the West of England for producing the figures and Wendy Woodland and Caedmon Staddon for comments on drafts of the manuscript.

\section{References}

Aide, T.M. and Rivera, E. 1998: Geographic patterns of genetic diversity in Poulsenia armata (Moraceae): implications for the theory of Pleistocene refugia and the importance of riparian forest. Journal of Biogeography 25, 695-705.

Allaby, M. 1994: The concise Oxford dictionary of ecology. Oxford: Oxford University Press.

Alvarez-Buylla, E.R. and Martinez-Ramos, $M$. 1992: Demography and allometry of Cecropia obtusifolia, a neotropical pioneer tree - an evaluation of the climax-pioneer paradigm for tropical rain forests. Journal of Ecology 80, 275-90.

Anstett, M.C., Hossaert-McKey, M. and Kjellberg, F. 1997: Figs and fig pollinators: evolutionary conflicts in a coevolved mutualism.
Trends in Ecology and Evolution 12, 94-99.

Aronson, R.B. and Precht, W.F. 1995: Landscape patterns of reef coral diversity - a test of the intermediate disturbance hypothesis. Journal of Experimental Marine Biology and Ecology 192, $1-14$.

Ashton, P.S. 1964: Ecological studies in the mixed dipterocarp forests of Brunei State. Oxford Forestry Memoir 25.

- 1969: Speciation among tropical forest trees. Some deductions in the light of recent evidence. Biological Journal of the Linnean Society 1, 155-96.

1977: A contribution of rain forest research to evolutionary theory. Annals of the Missouri Botanical Garden 64, 694-705.

Aubréville, A. 1938: La forêt coloniale; les forêts 
de l'Afrique occidentale Française. Annuelle Académie Science Coloniale 9, 1-245.

Augspurger, C.K. 1983: Seed dispersal of the tropical tree, Platypodium elegans, and the escape of its tree seedlings from fungal pathogens. Journal of Ecology 71, 759-71.

Axelrod, D.I. and Raven, P.H. 1978: Late Cretaceous and Tertiary vegetation history of Africa. In Werger, M.J.A., editor, Biogeography and ecology of southern Africa. The Hague: Dr W. Junk Publishers, 77-130.

Basset, Y. 1999: Diversity and abundance of insect herbivores on seedlings in a rainforest in Guyana. Ecological Entomology 24, 245-59.

Bian, L. and Walsh, S.J. 1993: Scale dependencies of vegetation and topography in a mountainous environment in Montana. Professional Geographer 45, 1-11.

Bowman, D.M.J.S. 1996: Tropical rain forests. Progress in Physical Geography 20, 224-30.

Bradbury, J.P., Leyden, B., Salgado-Labouriau, M., Lewis Jr., W.M., Schubert, C., Binford, M.W., Frey, D.G., Whitehead, D.R. and Weibezahn, F.H. 1981: Late Quaternary Environmental history of Lake Valencia, Venezuela. Science 214, 1299-1305.

Brokaw, N.V.L. 1985a: Treefalls, regrowth and community structure in tropical forests. In Pickett, S.T.A. and White, P.S., editors, The ecology of natural disturbance and patch dynamics. London: Academic Press, 53-69.

- 1985b: Gap-phase regeneration in a tropical forest. Ecology 66, 682-87.

- 1987: Gap-phase regeneration of three pioneer tree species in a tropical forest. Journal of Ecology 75, 9-19.

Brokaw, N.V.L. and Scheiner, S.M. 1989: Species composition in gaps and structure of a tropical forest. Ecology 70, 538-41.

Brown, E.D. and Hopkins, M.J.G. 1996: How New Guinea rain forest flower resources vary in time and space: implications for nectarivorous birds. Australian Journal of Ecology 21, $363-78$

Brown, J.H. and Kodric-Brown, A. 1977: Turnover rates in insular biogeography: effect of immigration and extinction. Ecology 58, $445-49$.

Brown, N.D. and Whitmore, T.C. 1992: Do dipterocarp seedlings really partition tropical rain forest gaps? Philosophical Transactions of the Royal Society of London Series B 335, 369-78.

Brown, N., Press, M. and Bebber, D. 1999: Growth and survivorship of dipterocarp seedlings: differences in shade persistence create a special case of dispersal limitation. Philosophical Transactions of the Royal Society of London Series B 354, 1847-55.

Burnham, R.J. and Graham, A. 1999: The history of neotropical vegetation: new developments and status. Annals of the Missouri Botanical Garden 86, 546-89.

Burslem, D.F.R.P. and Whitmore, T.C. 1999: Species diversity, susceptibility to disturbance and tree population dynamics in tropical rain forest. Journal of Vegetation Science 10, 767-76.

Bush, M.B. 1994: Amazonian speciation: a necessarily complex model. Journal of Biogeography 21, 5-17.

Bush, M.B., Piperno, D.R., Colinvaux, C.A., De Oliviera, P.E., Krissek, L.A., Miller, M.C. and Rowe, W.L. 1993: A 14,300-yr paleoecological profile of a lowland tropical lake in Panama. Ecological Monographs 62, 251-75.

Chown, S.L. and Gaston, K.J. 2000: Areas, cradles and museums: the latitudinal gradient in species richness. Trends in Ecology and Evolution 15, 311-15.

Clark, D.A. and Clark, D.B. 1984: Spacing dynamics of a tropical rain forest tree: evaluation of the Janzen-Connell model. The American Naturalist 124, 769-88.

_ 1992: Life history diversity of canopy and emergent trees in a neotropical rain forest. Ecological Monographs 62, 315-44.

Clark, D.B. and Clark, D.A. 1987: Population and microhabitat distribution of Dipteryx panamensis in a neotropical rain forest emergent tree. Biotropica 19, 236-44.

Clark, D.B., Palmer, M.W. and Clark, D.A. 1999: Edaphic factors and the landscape-scale distributions of tropical rain forest trees. Ecology 80, 2662-75.

Cochrane, M.A. and Schulze, M.D. 1999: Fire as a recurrent event in tropical forests of the eastern Amazon: effects on forest structure, biomass and species composition. Biotropica 31, 2-16.

Colinvaux, P.A. 1979: The ice age Amazon. Nature 278, 399-400.

1986: Ecology. Chichester: John Wiley and Sons.

1989: Ice age Amazon revisited. Nature 340, 188-89.

1997: An arid Amazon? Trends in Ecology and Evolution 12, 318-19.

- 1998: A new vicariance model for Amazonian endemics. Global Ecology and Biogeography Letters 7, 95-96.

Colinvaux, P.A., De Oliviera, P.E., Moreno, J.E., 
Miller, M.C. and Bush, M.B. 1996: A long pollen record from lowland Amazonia: forest and cooling in glacial times. Science 247, 85-88.

Colyn, M., Gauter-Hion, A. and Verheyen, W. 1991: A re-appraisal of palaeoenvironmental history in Central Africa: evidence for a major fluvial refuge in the Zaire Basin. Journal of Biogeography 18, 403-407.

Connell, J.H. 1971: On the role of natural enemies in preventing competitive exclusion in some marine animals and in rain forest trees. In den Boer, P.J. and Gradwell, G.R., editors, Dynamics of populations. Wageningen: Pudoc, 298-312.

- 1978: Diversity in tropical rainforests and coral reefs. Science 199, 1302-10.

Connell, J.H. and Orias, E. 1964: The ecological regulation of species diversity. American Naturalist 98, 387-414.

Connor, E.F. 1986: The role of Pleistocene forest refugia in the evolution and biogeography of tropical biotas. Trends in Ecology and Evolution 1, 165-68.

Cook, S. 1998: A diversity of approaches to the study of species richness. Trends in Ecology and Evolution 13, 340-41.

Cowling, R.M., Macdonald, I.A.W. and Simmons, M.T. 1996a: The Cape Peninsula, South Africa: physiographical, biological and historical background to an extraordinary hotspot of biodiversity. Biodiversity and Conservation 5, 527-50.

Cowling, R.M., Rundel, P.W., Lamont, B.B., Arroyo, M.K. and Arianoutsou, M. 1996b: Plant diversity in Mediterranean-climate regions. Trends in Ecology and Evolution 11, 362-66.

Cox, C.B. and Moore, P.D. 1993: Biogeography: an ecological and evolutionary approach. Oxford: Blackwell Science.

Crane, P.R. and Lidgard, S. 1989: Angiosperm diversification and paleolatitudinal gradients in Cretaceous floristic diversity. Science 246, 675-768.

Cullinan, V.I. and Thomas, J.M. 1992: A comparison of quantitative methods for examining landscape pattern and scale. Landscape Ecology 7, 211-27.

Dalling, J.W., Lovelock, C.E. and Hubbell, S.P. 1999: Growth responses of two neotropical pioneer species to simulated forest gap environments. Journal of Tropical Ecology 15, 827-39.

Damuth, J.E. and Fairbridge, R.W. 1970: Equatorial Atlantic deep sea arkosic sands and ice-age aridity in tropical South America. Bulletin of the Geological Society of America 81,
189-206.

Darlington, P.J. 1959: Zoogeography: the geographical distribution of animals. New York: Wiley.

Darwin, C. 1845: The voyage of the Beagle. London: Dent (1959 edition).

Davies, S.J. 1998: Photosynthesis of nine pioneer Macaranga species from Borneo in relation to life history. Ecology 79, 2292-308.

Dobson, A.P. 1996: Conservation and biodiversity. New York: Scientific American Library.

Dutson, G. and Branscombe, J. 1990: Rainforest birds in south west Ghana. ICPB Study Report 46. Cambridge: International Council for Bird Protection.

Endler, J.A. 1982: Pleistocene forest refuges: fact or fancy? In Prance, G.T., editor, Biological diversification in the tropics. New York: Columbia University Press, 641-57.

Federov, A.A. 1966: The structure of the tropical rain forest and speciation in the humid tropics. Journal of Ecology 54, 1-11.

Ferreira, L.V. 1997: Effects of the duration of flooding on species richness and floristic composition in three hectares in the Jaú National Park in floodplain forests in central Amazonia. Biodiversity and Conservation 6, 1353-63.

Ferreira, L.V. and Prance, G.T. 1998: Structure and species richness of low-diversity floodplain forest on the Rio Tapajós, Eastern Amazonia, Brazil. Biodiversity and Conservation 7, 585-96.

Fjeldså, J. and Lovett, J.C. 1997: Geographical patterns of old and young species in African forest biota: the significance of specific montane areas as evolutionary centres. Biodiversity and Conservation 6, 325-46.

Flenley, J. 1993: The origins of diversity in tropical rain forests. Trends in Ecology and Evolution 8, 119-20.

Forget, P.-M. 1992: Regeneration ecology of Eperua grandiflora (Caesalpiniaceae), a largeseeded tree in French Guiana. Biotropica 24, $146-56$.

Fraser, R.H. and Currie, D.J. 1996: The species richness-energy hypothesis in a system where historical factors are thought to prevail: coral reefs. American Naturalist 148, 138-59.

Gause, G.F. 1934: The struggle for existence. New York: Macmillan.

Gentry, A.H. 1989: Speciation in tropical forests. In Holm-Nielson, L.B., Nielson, I.C. and Balslev, H., editors, Tropical forests. New York: 
Academic Press, 113-34.

1992: Tropical forest biodiversity: distribution patterns. Oikos 63, 19-28.

Grubb, P. 1982: Refuges and dispersal in the speciation of African forest mammals. In Prance, G.T., editor, Biological diversification in the tropics. New York: Columbia University Press, 537-53.

Haffer, J. 1969: Speciation in Amazon rainforest birds. Science 165, 131-37.

Haila, Y. 1990: Toward an ecological definition of an island: a north-west European perspective. Journal of Biogeography 17, 561-68.

Hall, J.B. and Swaine, M.D. 1976: Classification and ecology of closed-canopy forest in Ghana. Journal of Ecology 64, 913-51.

- 1981: Distribution and ecology of vascular plants in a tropical rain forest: forest vegetation in Ghana. The Hague: Dr W. Junk Publishers.

Hammond, D.S., Brown, V.K. and Zagt, R. 1999: Spatial and temporal patterns of seed attack and germination in a large-seeded neotropical tree species. Oecologia 119, 208-18.

Hardin, G. 1960: The competitive exclusion principle. Science 131, 1292-97.

He, F., Legendre, P. and LaFrankie, J.V. 1996: Spatial pattern of diversity in a tropical rain forest in Malaysia. Journal of Biogeography 23, $57-74$.

Hill, J.L. 1995: The effect of forest spatial geometry on tree species diversity in tropical forest patches. Unpublished Ph.D. Thesis, University of Wales, $506 \mathrm{pp}$.

Hill, J.L. and Curran, P.J. 2001: Species composition in fragmented forests: conservation implications of changing forest area. Applied Geography 21, 157-74.

Hill, J.L., Curran, P.J. and Foody, G.M. 1994: The effect of sampling on the species-area curve. Global Ecology and Biogeography Letters 4, 97-106.

Holling, C.S. 1992: Cross-scale morphology, geometry and dynamics of ecosystems. Ecological Monographs 62, 447-502.

Hoogihiemstra, H. and van der Hammen, T. 1998: Neogene and Quaternary development of the neotropical rain forest: the forest refugia hypothesis and a literature overview. Earth Science Reviews 44, 147-83.

Hubbell, S.P. and Foster, R.B. 1986: Biology, chance and history and the structure of tropical rain forest tree communities. In Diamond, J. and Case, T.J., editors, Community ecology. New York: Harper and Row, 314-29.

Hubbell, S.P., Condit, R. and Foster, R.B. 1990:
Presence and absence of density dependence in a neotropical tree community. Philosophical Transactions of the Royal Society of London Series B 330, 269-81.

Hubbell, S.P., Foster, R.B., O'Brien, S.T., Harms, K.E., Condit, R., Wechsler, B., Wright, S.J. and Loo da Lao, S. 1999: Light-gap disturbances, recruitment limitation, and tree diversity in a neotropical forest. Science 283, 554-57.

Hutchinson, G.E. 1959: Homage to Santa Rosalia, or why are there so many different kinds of animals? American Naturalist 93, 145-59.

Imbert, D., Rousteau, A. and Labbe, P. 1998 Hurricanes and biological diversity in tropical forests - the case of Guadeloupe. Acta Oecologica 19, 251-62.

Iwasa, Y., Kubo, T. and Sato, K. 1995: Maintenance of forest species diversity and latitudinal gradient. Vegetatio 121, 127-34.

Janzen, D.H. 1970: Herbivores and the number of tree species in tropical forests. American Naturalist 104, 501-28.

Jones, R.L. and Keen, D.H. 1993: Pleistocene environments in the British Isles. London: Chapman and Hall.

Kauffman, J.B. 1991: Survival by sprouting following fire in tropical forests of the eastern Amazon. Biotropica 23, 219-24.

Kaufmann, S., McKey, D.B., Hossaert-McKey, M. and Horvitz, C.C. 1991: Adaptations for a two-phase seed dispersal system involving vertebrates and ants in a hemiepiphytic fig (Ficus microcarpa: Moraceae). American Joumal of Botany 78, 971-77.

Kellman, M. and Meave, J. 1997: Fire in the tropical gallery forests of Belize. Journal of Biogeography 24, 23-34.

Kobe, R.K. 1999: Light gradient partitioning among tropical tree species through differential seedling mortality and growth. Ecology 80, 187-201.

Korning, J. and Balslev, H. 1994: Growth and mortality of trees in Amazonian tropical rain forest in Ecuador. Journal of Vegetation Science 4, 77-86.

Krebs, C.J. 1985: Ecology: the experimental analysis of distribution and abundance. New York, NY: Pearson Education Inc.

Kursar, T.A. and Coley, P.D. 1999: Contrasting modes of light acclimation in two species of the rainforest understorey. Oecologia 121, 489-98. 
Laurance, W.F. and Bierregaard, R.O. 1997: Tropical forest remnants: ecology, management and conservation of fragmented communities. Chicago: University of Chicago Press.

Laurance, W.F., Ferreira, L.V., Rankin-de Morena, J.M. and Laurance, S.G. 1998: Rainforest fragmentation and the dynamics of Amazonian tree communities. Ecology 79, 2032-40.

Lewin, R. 1989: Biologists disagree over bold signature of nature. Science 244, 527-28.

Lieberman, D. 1982: Seasonality and phenology in a dry tropical forest in Ghana. Journal of Ecology 70, 791-806.

Lieberman, M., Lieberman, D. and Vandermeer, J.H. 1988: Age-size relationships and growth behaviour of the palm Welfia georgii. Biotropica 20, 270-73.

Liu, K. and Colinvaux, P.A. 1985: Forest changes in the Amazon Basin during the last glacial maximum. Nature 318, 556-57.

Lugo, A.E., Rogers, C. and Nixon, S. 2000: Hurricanes, coral reefs and rainforests: resistance, ruin and recovery in the Caribbean. Ambio 29, 106-14.

Mabberley, D.J. 1983: Tropical rain forest ecology. Glasgow: Blackie.

MacArthur, R.H. and MacArthur, J. 1961: On bird species diversity. Ecology 42, 594-98.

MacArthur, R.H. and Wilson, E.O. 1967: The theory of island biogeography. Princeton NJ: Princeton University Press.

MacDougall, A. and Kellman, M. 1992: The understorey light regime and patterns of tree seedlings in tropical riparian forest patches. Journal of Biogeography 19, 667-75.

Manrubia, S.C. and Sole, R.V. 1996: Self organised criticality in rain forest dynamics. Chaos, Solitons and Fractals 7, 523-41.

Martin, C. 1991: The rainforests of West Africa. Basel: Birkhauser Verlag.

Meave, J. and Kellman, M. 1994: Maintenance of rain forest diversity in riparian forests of tropical savannas: implications for species conservation during Pleistocene drought. Journal of Biogeography 21, 121-35.

Meentemeyer, V. and Box, E.O. 1987: Scale effects in landscape studies. In Turner, M.G., editor, Landscape heterogeneity and disturbance. New York: Springer-Verlag, 15-34.

Moravie, M.A., Pascal, J.P. and Auger, P. 1997: Investigating canopy regeneration processes through individual-based spatial models: application to a tropical rain forest. Ecological Modelling 104, 241-66.
Mori, S.A. and Brown, J.L. 1994: Report on wind dispersal in a lowland moist forest in central French Guiana. Brittonia 46, 105-25.

Morin, P.J. 2000: Biodiversity's ups and downs. Nature 406, 463-64.

Myers, N., Mittermeier, R.A., Mittermeier, C.G., da Fonseca, G.A.B. and Kent, J. 2000: Biodiversity hotspots for conservation priorities. Nature 403, 853-58.

Nelson, B.W., Ferreira, C.A.C., da Silva, M.F. and Kawasaki, M.L. 1990: Endemisim centres, refugia and botanical collection density in Brazilian Amazonia. Nature 345, 714-16.

Newbery, D.M., Campbell, E.J.F., Proctor, J. and Still, M.J. 1996: Primary lowland dipterocarp forest at Danum Valley, Sabah, Malaysia: species composition and pattern in the understorey. Vegetatio 122, 193-220.

Niklas, K.J., Tiffney, B.H. and Knoll, A.H. 1983: Patterns in vascular plant land diversification. Nature 303, 614-16.

Odum, E.P. 1969: The strategy of ecosystem development. Science 164, 262-70.

Ojo, L.O. and Ola-Adams, B.A. 1996: Measurement of tree diversity in the Nigerian rain forest. Biodiversity and Conservation 5, 1253-70.

Okuda, T., Kachi, N., Yap, S.K. and Manokaran, N. 1997: Tree distribution pattern and fate of juveniles in a lowland tropical rain forest implications for regeneration and maintenance of species diversity. Plant Ecology 131, 155-71.

Patton, J.L., da Silva, M.N.F. and Malcolm, J.R. 1994: Gene genealogy and differentiation among arboreal spiny rats (Rodentia: echimyidae) of the Amazon basin: a test of the riverine barrier hypothesis. Evolution 48, 1314-23.

Penfold, G.C. and Lamb, D. 1999: Species coexistence in an Australian subtropical rain forest: evidence for compensatory mortality. Journal of Ecology 87, 316-29.

Phillips, O. 1997: The changing ecology of tropical forests. Biodiversity and Conservation 6 , 291-311.

Phillips, O., Hall, P., Sawyer, S. and Vasquez, R. 1997: Species richness, tropical forest dynamics, and sampling: response to Sheil. Oikos 79 183-87.

Pickett, S.T.A. 1983: Differential adaptation of tropical tree species to canopy gaps and its role in community dynamics. Tropical Ecology 24, 68-84. 
Pickett, S.T.A. and White, P.S. 1985: The ecology of natural disturbance and patch dynamics. Orlando: Academic Press.

Pires, J.M. and Prance, G.T. 1985: The vegetation types of the Brazilian Amazon. In Prance, G.T. and Lovejoy, T.E., editors, Key environments: Amazonia. Oxford: Pergamon Press, 109-45.

Poore, M.E.D. 1968: Studies in Malaysian rain forest 1 . The forest on Triassic soils in Jangka Forest Reserve. Journal of Ecology 56, 143-96.

Prance, G.T. 1977: The phytogeographic subdivisions of Amazonia and their influence on the selection of biological reserves. In Prance, G.T. and Elias, T.S., editors, Extinction is forever. New York: New York Botanical Garden, 195-213.

- 1983: American tropical forests. In Golley, F.B., editor, Ecosystems of the world. New York: Elsevier, 99-132.

1990: Consensus for conservation. Nature 345,384 .

- 1996: Islands in Amazonia. Philosophical Transactions of the Royal Society of London Series $B$ 351, 823-33.

Proctor, J. 1986: Tropical rain forest: structure and function. Progress in Physical Geography 10, 383-400.

Proctor, J., Anderson, J.M., Chai, P. and Vallack, H.W. 1983: Ecological studies in four contrasting rain forests in Gunung Mulu National Park, Sarawak I. Forest environment, structure and floristics. Journal of Ecology 71, $237-60$.

Puhakka, M., Kalliola, R., Rajasilta, M. and Salo, J. 1992: River types, site evolution and successional vegetation patterns in Peruvian Amazonia. Journal of Biogeography 19, 651-65.

Putz, F.E. 1984: The natural history of lianas on Barro Colorado Island, Panama. Ecology 65, 1713-24.

Raich, J.W. and Christensen, N.L. 1989: Malaysian dipterocarp forest: tree seedling and sapling species composition and small-scale disturbance patterns. National Geographic Research 5, 348-63.

Richards, P.W. 1969: Speciation in the tropical rain forest and the concept of the niche. Biological Journal of the Linnean Society 1, 149-54.

— 1996: The tropical rainforest. Second edition. Cambridge: Cambridge University Press.

Ricklefs, R.E. 1987: Community diversity: relative roles of local and regional processes. Science 235, 167-71.

Rignot, E., Salas, W.A. and Skole, D.L. 1997: Mapping deforestation and secondary growth in Rondonia, Brazil, using imaging radar and Thematic Mapper data. Remote Sensing of the Environment 59, 167-79.

Rosenzweig, M.L. 1995: Species diversity in space and time. Cambridge: Cambridge University Press.

Runkle, J.R. 1989: Synchrony of regeneration, gaps and latitudinal differences in tree species diversity. Ecology 70, 546-47.

Rylands, A.B. 1990: Priority areas for conservation in the Amazon. Trends in Ecology and Evolution 5, 240-41.

Salo, J., Kalliola, R., Häkinnen, I., Mäkinen, Y., Niemelä, P., Puhakka, M. and Coley, P.D. 1986: River dynamics and the diversity of Amazon lowland forest. Nature 322, 254-58.

Sanchez-Hidalgo, M.E., Martinez-Ramos, M. and Espinosa-Garcia, F.J. 1999: Chemical differentiation between leaves of seedlings and spatially close adult trees from the tropical rainforest species Nectandra ambigens (Lauraceae): an alternative test of the Janzen-Connell model. Functional Ecology 13, 725-32.

Sayer, J. A. and Whitmore, T.C. 1991: Tropical moist forest: destruction and species extinction. Biological Conservation 55, 199-213.

Schimper, A.F.W. 1903: Plant-geography upon a physiological basis. Oxford: Oxford University Press.

Schneider, C. and Moritz, C. 1999: Rainforest refugia and evolution in Australia's wet tropics. Proceedings of the Royal Society of London Series B 266, 191-96.

Schneider, C.J., Smith, T.B., Larison, B. and Moritz, C. 1999: A test of alternative models of diversification in tropical rainforests: ecological gradients versus rainforest refugia. Proceedings of the National Academy of Sciences of the United States of America 96, 13869-73.

Schwilk, D.W., Keeley, J.E. and Bond, W.J. 1997: The intermediate disturbance hypothesis does not explain fire and diversity pattern in fynbos. Plant Ecology 132, 77-84.

Sheila, D. 1996: Species richness, tropical forest dynamics and sampling: questioning cause and effect. Oikos 587-90.

Shimabukuro, Y.E., Batista, G.T., Mello, E.M.K., Moreira, J.C. and Duarte, V. 1998: Using shade fraction image segmentation to evaluate deforestation in Landsat Thematic Mapper images of the Amazon region. International Journal of Remote Sensing 19, 535-42.

Skole, D. and Tucker, C. 1993: Tropical deforestation and habitat fragmentation in the Amazon: 
satellite data from 1978 to 1988 . Science 260 , 1905-10.

Smith, T.B., Wayne, R.K., Girman, D.J. and Bruford, M.W. 1997: A role for ecotones in generating rain forest biodiversity. Science 276, 1855-57.

Street Perrott, F.A., Roberts, N. and Metcalfe, S. 1985: Geomorphic implications of late Quaternary hydrological and climatic changes in the northern hemisphere tropics. In Douglas, I. and Spencer, T., editors, Environmental change and tropical geomorphology. London: Allen and Unwin, 167-83.

Strong, D.R. 1977: Epiphyte loads, tree falls and perennial forest disruption: a mechanism for maintaining higher tree species richness in the tropics without animals. Journal of Biogeography 4, 215-18.

Svenning, J.C. 2000: Small canopy gaps influence plant distributions in the rain forest understorey. Biotropica 32, 252-61.

Swaine, M.D. and Hall, J.B. 1988: The mosaic theory of forest regeneration and the determination of forest composition in Ghana. Journal of Tropical Ecology 4, 253-69.

Tabarelli, M., Mantovani, W. and Peres, C.A. 1999: Effects of habitat fragmentation on plant guild structure in the montane Atlantic forest of southeastern Brazil. Biological Conservation 91, 119-27.

Terborgh, J. 1992: Diversity and the tropical rain forest. New York: Scientific American Library.

Terborgh J. and Mathews J. 1999: Partitioning of the understorey light environment by two Amazonian treelets. Journal of Tropical Ecology 15, 751-63.

Terborgh, J., Foster, R.B. and Nunez, P. 1996: Tropical tree communities: a test of the nonequilibrium hypothesis. Ecology 77, 561-67.

Tilman, D. 1994: Diversity by default. Science 283, 495-96.

Tracy, C.R. and Brusard, P.F. 1994: Preserving biodiversity: species in landscapes. Ecological Applications 4, 205-207.

TReeS 1994: Report of the TReeS TambopataCandamo Expedition. A Biological Survey in the Tambopata-Candamo Reserved Zone, South-East Peru (12 August-20 September 1992). Unpublished expedition report by the Tampopata Reserve Society.

Tuomisto, H., Ruokolainen, K., Kalliola, R., Linna, A., Danjoy, W. and Rodriguez, Z. 1995: Dissecting Amazonian biodiversity. Science 269, 63-66.

Turcq, B., Sifeddine, A., Martin, L., Absy, M.L.,
Soubies, F., Sugulo, K. and Volkmer-Ribeiro, C. 1998: Amazonia rainforest fires: A lacustrine record of 7,000 years. Ambio 27, 139-42.

Turner, I.M. 1996: Species loss in fragments of tropical rain forest: a review of the evidence. Journal of Applied Ecology 33, 200-209.

Valencia, R., Balslev, H. and Paz y Mio, G. 1994: High tree alpha-diversity in Amazonian Ecuador. Biodiversity and Conservation 3, 21-28.

VanderMeer, P.J. and Bongers, F. 1996: Patterns of tree-fall and branch-fall in a tropical rain forest in French Guiana. Journal of Ecology 84, 19-29.

van Shaik, C.P. and Mirmanto, E. 1985: Spatial variation in the structure and litterfall of a Sumatran rain forest. Biotropica 17, 196-205.

Van Woesik, R. 2000: Modelling processes that generate and maintain coral community diver-sity. Biodivesity and Conservation 9, 1219-33.

Wallace, A.R. 1878: Tropical nature and other essays. London: Macmillan.

Walsh, R.P.D. 1996a: Climate. In Richards, P.W. editor, The tropical rainforest. Cambridge: Cambridge University Press, 159-205.

1996b: Drought frequency changes in Sabah and adjacent parts of northern Borneo since the late nineteenth century and possible implications for tropical rain forest dynamics. Journal of Tropical Ecology 12, 385-407.

Watt, A.S. 1947: Pattern and process in the plant community. Journal of Ecology 35, 1-22.

Webb, E.L., Stanfield, B.J. and Jensen, M.L. 1999: Effects of topography on rainforest tree community structure and diversity in American Samoa, and implications for frugivore and nectarivore populations. Journal of Biogeography 26, 887-97.

Welden, C.W., Hewett, S.W., Hubbell, S.P. and Foster, R.B. 1991: Sapling survival, growth and recruitment: relationship to canopy height in a neotropical forest. Ecology 72, 35-50.

Whitmore, T.C. 1974: Changes with time and the role of cyclones in Tropical rain forest on Kolombangara, Solomon Islands. Commonwealth Forestry Institute 46.

- 1978: Gaps in the forest canopy. In Tomlinson, P.B. and Zimmerman, M.H. editors, Tropical trees as living systems. Cambridge: Cambridge University Press, 639-55.

1984: Tropical rain forests of the Far East. Second Edition. Oxford: Clarendon Press.

- 1989: Changes over 21 years in the 
Kolombargara rainforests. Journal of Ecology 77, 469-83.

1990: An introduction to tropical rain forests. Oxford: Clarendon Press.

Whitmore, T.C. and Prance, G.T. 1987: Biogeography and Quaternary history in tropical America. Oxford: Oxford University Press.

Whitmore, T.C. and Sayer, J.A. 1992: Tropical deforestation and species extinction. London: Chapman and Hall.

Whittaker, R.H. 1972: Evolution and measurement of species diversity. Taxon 21, 213-51.

Whittaker, R.J., Bush, M.B. and Richards, K.
1989: Plant recolonisation and vegetation succession on the Krakatau islands, Indonesia. Ecological Monographs 59, 59-123.

Wiens, J.A. 1989: Spatial scaling in ecology. Functional Ecology 3, 385-97.

Wills, C. and Condit, R. 1999: Similar nonrandom processes maintain diversity in two tropical rainforests. Proceedings of the Royal Society of London Series B 266, 1445-52.

Wilson, E.O. 1988: Biodiversity. Washington, DC: National Academy Press.

World Wide Fund for Nature 1988: Conservation of tropical forests. Special Report 1, Gland, Switzerland: WWF. 